\title{
Go West, Brother: The Politics of Landscape in the Blaxploitation Western
}

\author{
Austin Fisher
}

When The Legend of Nigger Charley (Martin Goldman, 1972) opened in downtown theaters across the United States in May 1972, its marketing campaign provided a clear indication of who its target audience was. The film's tagline- "Somebody warn the West. Nigger Charley ain't running no more"-locates it within the cultural moment of the "blaxploitation" cycle, appealing to inner-city black markets through an antagonistic opposition to white America's most hallowed foundation myth. Yet this belligerent tone belies the hesitance and uncertainty toward the Wild West, its landscape, and the attendant tropes that are to be found in the film itself. After the eponymous hero and his two fellow escapees kill their brutal white slave-master and flee into the desert from an antebellum plantation, the first encounter they actually have with "the West" is rather less assured than the tagline suggests. Charley (Fred Williamson) belatedly notices an impending ambush by a group of Native Americans and nervously says "let's keep moving," but the trio are rapidly surrounded and brought to a halt. As the outlaws look around anxiously, one young tribesman reaches out, wipes his fingers down Charley's cheek and checks to see if the color has rubbed off, before confirming to his companions that it has not. A visibly relieved Charley responds by returning the gesture, and our heroes are allowed to go on their way.

On a diegetic level, this scene gives a brief but clear indication that the black outlaws and the Native Americans are in sympathy with each other in their mutual opposition to white oppression. The tribesman's suspicion that the hero's skin color would rub off also serves as a humorous comment on the history of ethnic makeup in Hollywood westerns, described by Tom Engelhardt as "a vast minstrel show in which the Other was represented by a limited set of red-, black-, brown-, or yellow-face masks created by, and if important enough, worn by whites." Simultaneously, however, this scene shows the film's black characters to be bewildered outsiders in both the landscape and the historical setting of the Wild West: caught unawares, and finding themselves out of their depth in the wilderness. This chapter explores how such ambivalence toward the codes of the western genre characterized this and related films' more complex mode of address to their target audiences than the confrontational tone of their paratexts might suggest. 
The Legend of Nigger Charley was the most successful of a small hybrid cycle of blaxploitation westerns that played US inner-city circuits in the early to mid 1970s, including Soul Soldier (John Cardos, 1972), Charley One-Eye (1973 D D Soul of Nigger Charley (Larry G. Spangler, 1973), Thomasine and Bushrod (Goroon Parks Jr, 1974), Boss Nigger (Jack Arnold, 1974), and Take a Hard Ride (Antonio Margheriti, 1975). Though each film shows people of color uniting in resistance to a racist white America, the divisions between ethnic groups are more revealing than what unites them, consistently placing black outlaws as outsiders in the landscape, which is positioned classically as the terrain of the Native American, but also as that of the white man since it doubles as the Hollywood western's hallowed turf. In these films, black heroes are alienated by both nineteenth century white society and the great open spaces of the American continent. In their attitudes and outlooks, they instead seem "out of time": anachronistic representatives of a 1970s black urban sensibility, facilitating a mode of address located firmly in these films' immediate distribution contexts. Howard Thompson's review of The Legend of Nigger Charley in The New York Times gave a clear sense of the blaxploitation western's anachronistic feel, lamenting: "what has a blaring, jazzy rock 'n'roll sound-track got to do with the Old West or old anything?"2 His question is pertinent, and it is my intention to explore its implications for the films' broader signifying practices in the coming pages.

There is of course nothing new in examining how the racial coding of the western began to unravel toward the end of the 1960s and into the 1970s. Richard Slotkin, ${ }^{3}$ Tom Engelhardt, ${ }^{4}$ and Stanley Corkin, ${ }^{5}$ among others, have argued that the genre faced a crisis as the ideological assumptions on which it had previously thrived were dismantled in the Vietnam era. "Revisionist" westerns of the early 1970s in particular are a cause célèbre of politicized reappropriation, focusing in a self-conscious manner on the selective construction of history, and on recovering repressed historical narratives, as taglines for two of the most celebrated such films announced quite overtly. Soldier Blue (Ralph Nelson, 1970) was marketed as "the most savage film in history!," while one poster for Little Big Man (Arthur Penn, 1970) opened with the words "history lied." The word "history" was at the fore in both marketing campaigns, the films' sympathies for the wronged Native American inverting racial paradigms to register their countercultural outrage and to lay accusations of a continuum of genocidal impulses at white America's door. It is considerably less common to study the blaxploitation westerns, which also sought to reinscribe the classical western genre's racial codes for countercultural purposes - this time in the more confrontational tone of black separatism-and that played on urban grind house circuits a couple of years after these more celebrated revisionist examples. They tend to be left out of both scholarly histories of the western, and those of blaxploitation. Before I examine these films' modes of engagement with the landscapes and ideologies of the classical western, and their political and historical address to a 1970s inner-city audience, I will therefore consider why these scholarly omissions have occurred.

Their omission from accounts of the western might partly be due to the awkward "fit" that black-centered narratives had always had within that genre's mythos. Engelhardt argues that the historical presence of African Americans on the frontier 
was problematic to a binary construction of inexorable white progress set against the myth of the "vanishing American" (the native who mystically and obligingly "moves aside" to make room for white settlement): "Held in a tyrannical embrace within a democratic society, African-Americans could neither be incorporated into the inclusive narrative nor thrust beyond the geographic boundaries of the nation. Feared yet not an enemy, excluded yet close by, demeaned yet needed, they presented whites with an insoluble dilemma."6 Moreover, of course, the very presence of black people provided an uncomfortable historical reminder that white American notions of "liberty" extended only so far. For this reason, Engelhardt argues, their enslavement was relegated to an "aberrant sideshow," while the facts that 200,000 black soldiers had fought in the Civil War and that a quarter of late-nineteenth-century cowboys were black were mostly erased from the story in dime novels and western films alike. ${ }^{7}$

Engelhardt's argument places emphasis on the liminal position of black identity within the United States' national narrative, and thereby usefully identifies a generic precedent for the "outsider" status of Charley and the blaxploitation westerns' outlaw heroes. It is, however, in danger of oversimplifying the history of the western genre, since there is in fact a long ancestry of black westerns. One of the early so-called "race movies" (independent, black-produced films responding to the public furor caused by the racism of Birth of a Nation ${ }^{8}$ ) was Oscar Micheaux's 1919 drama The Homesteader, which — while not strictly speaking a "western"-explored issues around the settlement of the wilderness, and racial tensions with black homesteaders. In the late 1930s, blackaudience musical westerns such as Harlem on the Prairie (Sam Newfield, 1937), The Bronze Buckaroo (Richard C. Kahn, 1938), Two Gun Man from Harlem, and Harlem Rides the Range (both Richard C. Kahn, 1939) featured the black "singing cowboy" Herb Jeffries. Julia Leyda examines how these films, though ostensibly anodyne when compared to the earlier race movies' overt focus on contemporary racial politics, encouraged contemporary cultural identification among their audiences in all-black cinemas by employing "strategic anachronisms." She continues: "the result is a western that creates a dual present. The fictional characters appear to be in the classic western setting, the nineteenth century, but the anachronistic dialogue, the titles, and the costumes place the film firmly in the 1930s." This strategy of temporal displacement is further enhanced by three of the above films' titles incorporating the incongruous geographical referent "Harlem"- "the symbolic site of twentieth-century urban African American experience" - into a frontier lexicon. ${ }^{9}$

Indeed, Peter Stanfield has set out in great detail how the 1930s more broadly was a decade in which the western genre, though often supposed to be in crisis just prior to the onset of its golden age with the arrival of Stagecoach (John Ford, 1939), was in fact flourishing with rapidly produced series westerns. These were commonly set in a post-frontier West, and merged western iconography with Depression-era maladies of urban industrialization and working-class disenfranchisement, directly to address the concerns of lower-class audiences. Gene Autry himself underlined the extent to which the representation of history was very much subordinated to a contemporary mode of address in the 1930s "singing cowboy" format: "I played a kind of New Deal Cowboy who never hesitated to tackle many of the same problems [as Franklin D. Roosevelt]: 
the dust bowl, unemployment, or the harnessing of power. This may have contributed to my popularity with the 1930 s audiences." ${ }^{10}$ Leyda refers to Stanfield's work to argue for an equivalent process on behalf of the black singing cowboy films, which similarly addressed their audiences' immediate economic and geographical dislocations. ${ }^{11}$ In the pages that follow, I will argue that the blaxploitation western inherits the legacy of these low-budget "race westerns," whose overt contemporaneity was plain to see, this time by addressing the upheavals within racial politics in the late 1960s and early 1970s. Simultaneously, however, I shall argue that the blaxploitation western inherits and utilizes certain of the classical Hollywood western's ideological and racial associations, and therefore occupies an uncertain position within that genre's rich and varied history.

Of course, if I am adequately to contextualize these films within their cultural moment (and indeed within the remit of this book), they must also be considered alongside the wider blaxploitation trend of the early 1970s. This cycle of films emerged in response to a crisis in cinema audience numbers (brought about by the rise of television and the incursion of foreign films), and simultaneous shifts in postwar inner-city demographics. Variety estimated in 1967 that, while only 10-15 percent of the US population at that time were black, they totaled over 30 percent of audiences in first-run, big-city cinemas. ${ }^{12}$ By June 1972, The New York Times reported that "an informal survey made on a recent weekend revealed that over half of the patrons for all kinds of movies in the theaters on $42^{\text {nd }}$ Street and along Broadway ... were black." ${ }^{13}$ The resultant need to adapt cinematic business practices was clear to see, and in the same month The Boston Globe reported that "black audiences ... have become a major factor in cities throughout the country. With the number of urban blacks increasing and the move of whites to the suburbs, downtown movie theatre owners in many cities feel they must attract the blacks in order to survive." ${ }^{14}$ The films under consideration in this chapter were entwined within this socioeconomic context, emerging at the peak of blaxploitation's popularity after the huge successes of Sweet Sweetback's Baadasssss Song (Melvin van Peebles, 1971) and Shaft (Gordon Parks, 1971) had demonstrated the lucrative returns on offer to those willing to exploit the inner-city black market. Even once the blaxploitation trend had waned after 1973, as Hollywood's fiscal crises eased and objections from civil rights organizations to such films' racial stereotyping became more audible, these westerns continued to target black markets through both their content and their distribution patterns. ${ }^{15}$

It is therefore notable that the most successful blaxploitation westerns are often omitted or sidelined in literature about blaxploitation, even when the overt focus is on the trend's engagement with established industry genre categories. ${ }^{16}$ Novotny Lawrence breaks blaxploitation down into detective, horror, gangster, and cop variants, with brief mentions of westerns coming only in lists and filmographies, ${ }^{17}$ while Mikel J. Koven devotes a chapter to "Genre Films" but appraises only Adios Amigo (Fred Williamson, 1976) and Take a Hard Ride under the "westerns" category, and states that "neither ... are Blaxploitation films." 18 The reasons for such consistent omissions can, I think, be gleaned from the broader scholarly consensus that surrounds blaxploitation's sociopolitical contexts. Donald Bogle and Ed Guerrero both highlight 
the extent to which blaxploitation was a direct rejection of the integrationism that had characterized postwar "problem films," in particular those featuring the mildmannered, nonthreatening persona of Sidney Poitier-whom Bogle labeled "the model integrationist hero"19 - such as No Way Out (Joseph L. Mankiewicz, 1950), Edge of the City (Martin Ritt, 1957), and Guess Who's Coming to Dinner (Stanley Kramer, 1967). ${ }^{20}$ Blaxploitation's confrontational separatist messages, articulated and enacted by altogether more assertive black heroes, were seen by producers to be more in tune with the shifts in black sociopolitical consciousness in the era of the Civil Rights and Black Power movements. This critical focus on how blaxploitation films were overtly responding to the contemporary social realities of their intended audiences is of course crucial to an understanding of their success, but it runs the risk of demarcating their modes of engagement with those audiences in an ove-prescriptive manner. In a rundown of what constitutes "blaxploitation," Lawrence states that its films "are set in predominantly black urban spaces. Prior to the emergence of these films, allblack Hollywood motion pictures were generally set in the South. Blaxploitation films replace the traditional Southern settings with urban locales in cities like Harlem and Oakland."21

The assumption that emerges from such policing of the trend's boundaries is that, in order to qualify as "blaxploitation," a film must engage on a literal level with its target audiences' lived experience, by occupying the same urban spaces and addressing the same social and political issues. Yet this overlooks other, less literal, ways by which the films might address said audiences. The first half of The Legend of Nigger Charley is indeed set in the antebellum South, but if another of Lawrence's definitions for blaxploitation holds true- "movies made between 1970 and 1975, by both black and white filmmakers alike, to exploit the black film audience"22 - then all of the key westerns analyzed in this chapter should be considered in this context. Rather than meeting target audiences in their immediate and contemporary locales, these films adopt particular strategies for the exploitation of this inner-city market, based around cinematic genre convention rather than sociopolitical verisimilitude. The blaxploitation western is such an awkward fit within both of its parent genres precisely because it occupies what Leyda (referring to the 1930s black "singing cowboy" films) called a "dual present"23: simultaneously residing in a cinematically and historically "western" setting, while embedding itself in its immediate distribution context. These films are neither here nor there. They are fluid, hybrid texts, displaced both generically and temporally. Running contrary to Lawrence's demarcation of blaxploitation's settings, their rural locales are paradoxically central to their strategies of engagement with their urban audiences. Rather than rejecting the legacy of white America's cinematic myth par excellence (to misquote André Bazin ${ }^{24}$ ), their racial inscriptions are executed through ambivalent appropriation of the received landscapes of the classical Hollywood western, and the attendant ideological implications of those landscapes.

This ambivalence toward the conventions of the Hollywood western is at its most apparent when the films' black heroes encounter other ethnic minority groups. One of the most noticeable and repeated features of blaxploitation westerns-present in The Legend of Nigger Charley, and forming a decisive factor in the narrative developments of 
Charley One-Eye and Thomasine and Bushrod-is a consistent depiction of black outlaws discovering an affinity with Native Americans, the obvious point being that people of color should unite against the white oppressor. In this way, these films can be said to possess crossovers with the more celebrated revisionist western, with the classical genre's tables of racial representation being turned on the white society to unmask a genocidal counterhistory. What is notable about these depictions, though, are the differences they posit between black and Native American characters. Far from inverting the classical western's racially coded associations with the landscape, they borrow and utilize them, to present their audiences with black heroes who are alienated by both white society and the great open spaces of the North American continent. This is a key component of a broader and defining sense that these films' black outlaws are anachronistic time travelers, dropped in the middle of the cinematic Wild West from 1970s Harlem.

In each film, the black heroes are shown quite conspicuously to be uncomfortable in the wilderness. The Legend of Nigger Charley, for example, makes it very clear that its gang of black outlaws on the run is anything but the western's outlaw archetype of "men who know Indians." They are shown to be ignorant of what the word "squaw" means; they have never heard of the Rio Grande; and when they sit around a campfire to be introduced to the ways of the wild by the itinerant freed slave known as "Shadow," they shelter miserably from the rain, pull faces of disgust at the bush tea Shadow has
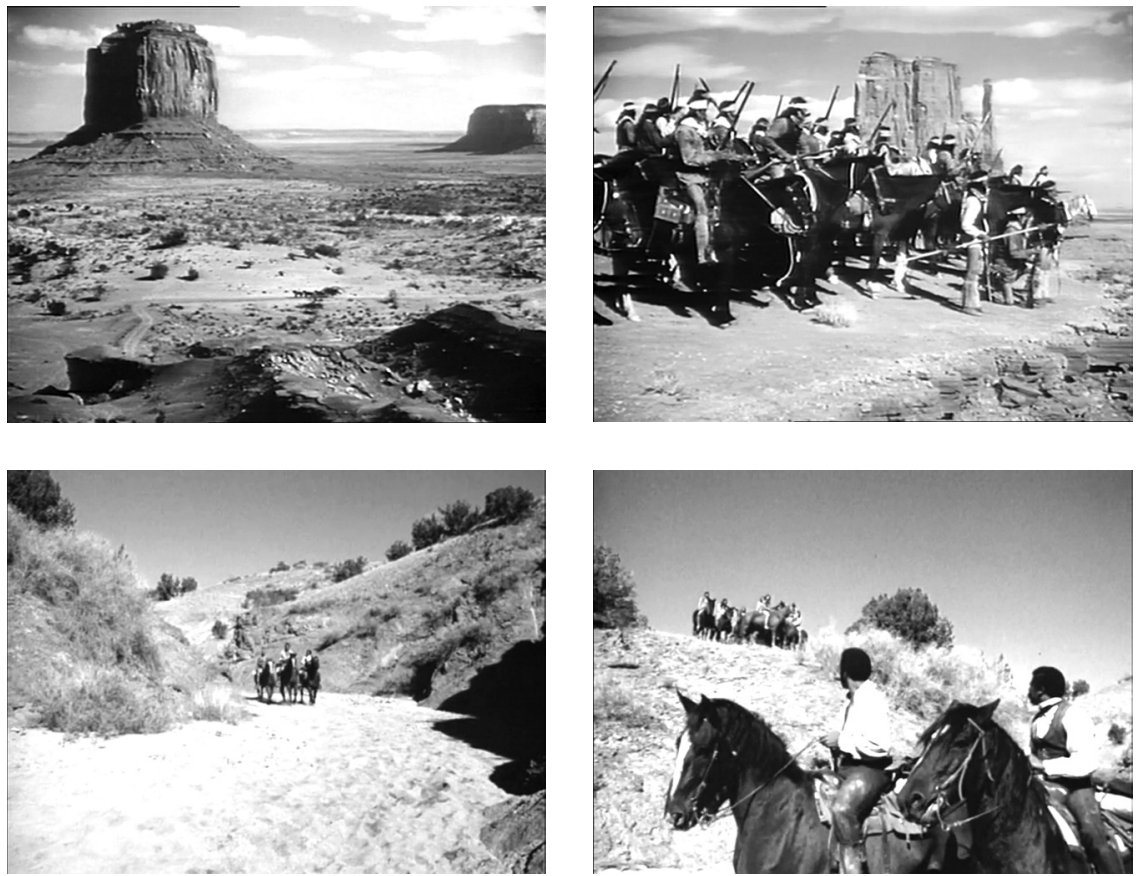

Figures 10.1-10.4 Equivalent framings of Native Americans in Stagecoach (1939) $(10.1,10.2)$ and The Legend of Nigger Charley $(1972)(10.3,10.4)$. 
served them, and cough and splutter on his pipe. They are also shown to lack guile in the wild since, as already outlined, they are easily ambushed by Native Americans, who seem to appear from nowhere, framing the natives as being "at one" with the landscape.

Furthermore, though it is executed with a lower budget and more basic production values, the aforementioned scene provides a clear visual association with one of the most iconic shots in the history of the western genre, and it inherits its racial coding. This can be demonstrated by a simple shot comparison with the mise-en-scène and camera movement as the lone titular vehicle enters the vast wilderness in Stagecoach (John Ford, 1939) (see Figures 10.1-10.4). In each shot, a Native American tribe enters the frame as the camera moves upwards and to the left to "discover" them standing on a high bluff, catching both the viewer and the protagonists-who are naively travelling along an exposed road-unawares. Each therefore offers a visual manifestation of Jim Kitses's seminal "shifting antinomies" paradigm, whereby the western genre negotiates US national identity by setting up a series of binary oppositions broadly symbolizing "wilderness" and "civilization." ${ }^{25}$ In each shot, the Native Americans are framed as being tied to or part of the arid landscape in juxtaposition to the protagonists, who are travelling through this landscape as endangered outsiders. The Legend of Nigger Charley borrows this association to assert the obvious point that, though they are in sympathy with each other, there are significant cultural differences dividing people of color. Yet, by placing the black heroes in the position of the ambushed traveler usually occupied by whites in the western's generic syntax, the film frames the Native in an altogether classical, not a revisionist, manner.

Indeed, it is certainly not the case that, simply because blaxploitation westerns are apt to frame black and Native American characters as being in sympathy with one another, they necessarily do anything to subvert or challenge the genre's dominant racial stereotypes. Charley One-Eye pairs two men referred to only as "The Black Man" and "The Indian" in an uneasy partnership between contrasting ethnicities, reminiscent of similar pairings in numerous spaghetti westerns (an association enhanced further by the film's location shooting in Almería). Accordingly, their ethnic identities are emphasized throughout, with stereotypical assumptions being made about The Indian in particular. He is relied upon and coerced by The Black Man to show resourcefulness in the wild, and to hunt and cook their food, while The Black Man refuses him a sip of whiskey, saying "I know what this stuff does to you redskins. You stay away from it." This characterization (along with the casting of Richard Roundtree, fresh from his starring role in Shaft) serves to reinforce The Black Man's role as a talkative, streetwise pragmatist with a cynically urban sensibility, in contrast to the taciturn Indian-a relationship typified by The Black Man asking "how about you and me robbing for a living?," to which The Indian responds "don't know how to rob." "There ain't nothing to know," counters The Black Man; "You just leave that to me."

Gordon Parks Jr.s Thomasine and Bushrod is a transparent reworking of the Bonnie and Clyde legend, moving the real Bonnie and Clyde's 1930s exploits into the relatively more "western" timeframe of 1911 and seeking to advance a more progressive message with a black outlaw couple robbing the (white) rich to give to the (black, Hispanic, and Native American) poor. The film borrows heavily from Arthur Penn's Bonnie and 
Clyde (1967), by focusing on the construction of the heroes' legendary status with sepia photographs intercut with their exploits, and the outlaws reading newspaper reports of their growing celebrity status. It also resembles Penn's film in the way it plays upon the contemporary countercultural pertinence of the Bonnie and Clyde story, framing its heroes as free-spirited youths rebelling against a bigoted white society, this time overlaid with an explicitly racial dimension as the black outlaw couple find succor in the mountains from a mixed race black/Native American couple. Yet, once again, this affinity between people of color is expressed through age-old associations with a Native connection to the wilderness. Bushrod's ability to tame horses and find his way through tribal holy ground is implicitly linked to the revelation that he is half Comanche, while Thomasine tries in vain to cook on a campfire, and ends up kicking over her impromptu spit in frustration.

While Native American roles in these films tend to draw upon well-worn racial stereotypes, this consistent sense that the black heroes would be more at home in an urban milieu provides the blaxploitation western with a revealing indication of its contemporary mode of address. The use of the western setting to symbolize and foreground these heroes' cultural alienation is not only predicated upon their relationship with natives; it is just as often used to frame their interaction with white society. The Legend of Nigger Charley starts with the heroes being incarcerated as slaves in the antebellum South, and only enters recognizably "western" terrain when Charley has killed his slave-master and fled as a fugitive. As he and his companions then enter the wilderness, they are pursued by a white posse, and here it is made clear that white people too are considerably more comfortable in the landscape than are the black outlaws. Upon seeing that their pursuers are still very close behind them, despite a montage of landscape shots suggesting that they have been fleeing for some time, Charley sits on a promontory and comments bitterly: "that damn white man won't let up." This lament is (perhaps deliberately) reminiscent of Butch Cassidy's (Paul Newman's) repeated utterance of "who the hell are those guys?" in Butch Cassidy and the Sundance Kid (George Roy Hill, 1969), suggesting that Thomasine and Bushrod was not the only blaxploitation western to appropriate for the racial politics of the 1970s a symbol of white rebellion that had been recently reimagined by New Hollywood. The association is certainly apt. Butch Cassidy is here expressing incredulity at the tenacity of the faceless system that pursues the free-spirited heroes through the landscape. By overlaying a racial dimension onto an association with this recently filmed icon of white countercultural sentiment, The Legend of Nigger Charley further enhances its contemporary credentials, and emphasizes its heroes' position at the margins of bourgeois society.

In a similar vein, Boss Nigger consistently frames the western landscape as being the habitat of the white man, which alienates and endangers black people who dare enter it. An early scene shows a black father and daughter being attacked by white outlaws, their wagon having been overturned and their possessions strewn over the desert floor. The symbolic inversion of the western's racial archetypes is clear to see, with the desecration of the pioneer wagon being committed by whites rather than Native Americans. When the hero (played by Fred Williamson) arrives to save the daughter, 
it also becomes apparent that black people are unwise to set foot in this terrain, as he asks incredulously "what y'all doing out here anyway?" Her reply-that they are looking for work-is revealing. Though they outwardly resemble the western genre's trope of a vulnerable "pioneer" family, they are in fact seeking to reach an alreadyfounded urban society, rather than settling in the wilderness. The film proceeds to underline this sense that black people do not "belong" in the western's landscape. The hero-a tough, uncompromising black bounty hunter-arrives in town and "sticks it to the Man" by proclaiming himself sheriff, outlawing racial slurs and imprisoning racist whites. Once again, however, it is the white man who is shown to be at home in the great outdoors, in stark and noticeable contrast to the hero who, the moment he leaves the town that he has taken charge of and enters the surrounding countryside, is caught in a laughably simple trap by the white posse seeking to catch him.

It is therefore apparent that, in the blaxploitation western, both white people and Native Americans are frequently shown to "belong" to the western genre and to the historical referents that accompany it. Black people, on the other hand, are consistently framed as conspicuous outsiders. The films utilize associations from the genre's history: framing Native Americans in their age-old role as being "of the land"; and framing whites as being "of the genre," since they too are shown easily to traverse the hallowed turf of white America's film genre par excellence. The black heroes are only shown to be in their element when they find an urban environment, as with Fred Williamson's sheriff in Boss Nigger, who is itinerant until he happens upon a lawless town, and sees the opportunity to enforce his "black man's law."

Before I draw conclusions about these trends of representation, there are a number of contextual factors that require clarification. I am not, for example, claiming that inner-city black audiences were necessarily inspired by these films. Nor am I claiming that blaxploitation westerns were expounding black nationalist doctrine in anything but the most superficial manner. My argument instead revolves around the identification of a particular mode of address and exploitation in this cultural moment, when US film producers were waking up to the lucrative returns on offer from the domestic black market, and tailoring their products accordingly. This hardheaded economic imperative was, of course, the origin and definition of the term "blaxploitation," and an appeal to black audiences was certainly not the same thing as black agency in the filmmaking process or an equal share of profits for black producers. In her study of the "black film" phenomenon between January 1973 and August 1974, Reneé Ward states plainly: "Black films are a box office bonanza at Chicago's Loop theaters, but mainly for white theater owners, producers and distributors." The picture she paints is a stark one in which, of the fifty-two "black-oriented" films released in the sample period, 75 percent were produced by whites, 57 percent were directed by whites, and none at all were distributed by black-owned companies. ${ }^{26}$

The blaxploitation westerns considered in this chapter were a part of this trend: both The Legend of Nigger Charley and The Soul of Nigger Charley were directed and produced by white filmmaker Larry G. Spangler, and distributed by Paramount; Charley OneEye was directed by Don Chaffey (white), produced by David Frost's company "David Paradine Productions," and also distributed by Paramount; Thomasine and Bushrod, 
though directed and coproduced by black filmmakers (Gordon Parks Jr and Max Julien respectively), was distributed by Columbia Pictures; while Boss Nigger was written and coproduced by Fred Williamson (black), but directed by Jack Arnold (white) and distributed by Dimension Pictures. ${ }^{27}$ Indeed, this factor was a bone of contention in the film press at the time of these films' releases. The Legend of Nigger Charley in particular drew the ire of critics in The New York Times, with its cynical "whiteness" being singled out in a number of articles during its first downtown and neighborhood runs. ${ }^{28}$ One critic, for example, described the sudden trend of movies featuring black cowboys and cops as "products of the same Hollywood minds that made millions of dollars while excluding Blacks from the industry. Now they've discovered a latter-day vein of gold to rip off." ${ }^{29}$

The notion that these films might be merely paying superficial lip service to the concerns of black audiences can to some extent be illustrated by their marketing strategies. Returning to the focus on taglines with which I began this chapter, Charley One-Eye's is particularly revealing: "Somebody told the black man he wasn't a slave anymore. Somebody told the red man this land was his. Somebody lied. Somebody is going to pay." This confrontational tone suggests that the narrative alliance between The Black Man and The Indian is to be predicated on a common grievance against whites, but the film itself sells this promise short. Charley One-Eye does not in fact address slavery or land rights at all, but instead revolves around a fugitive soldier, and a Native American whose only grievance and cause to kill a white man appears to be that the said white man shot his pet chicken (the titular "Charley One-Eye"). The sensationalist tagline is clearly present to sell this film to inner-city black audiences eager to see their heroes "stick it to the Man," and this extended to its wider marketing strategy. Reviewing Charley One-Eye in the Chicago Tribune, Gene Siskel criticized its misleading advertising campaign, in particular an advert in his own paper the previous week that

contains a picture of Richard Roundtree as Shaft-leather coat, black turtleneck, and revolver exploding from his waist-with the note, "The man you know as SHAFT in an exciting new role, defending 'Charley One-Eye." There is a crouching Indian beneath those words ... a number of people have stormed out of the Roosevelt Theater upon discovering that "Charley One-Eye" wasn't a "Shaft" adventure. ${ }^{30}$

Yet such opprobrium at "misleading" marketing presumes the "black audience" to be a discrete and politically unified entity. Jon Kraszewski has argued that blaxploitation scholarship focuses too much on the negative polemics and reviews about the films that arose from black pressure groups (and from those sympathetic to their causes). Such a focus, he suggests, constructs a monolithic black spectator and homogenizes "black experience" through a singular, reductive prism of "black nationalism," overlooking the ways in which other factors such as marketing materials "structured the historical reception of blaxploitation in the 1970s." ${ }^{31}$ Citing Barbara Klinger's model of cinematic "digressions," whereby promotional materials fracture the film and allow the spectator 
to follow numerous meanings (by focusing variously on the star, the genre or the director for example), ${ }^{32}$ Kraszewski sets out how blaxploitation's marketing strategies "articulated shifting forms of nationalism, black class relations, and anxiety; spectators could choose these articulations or rearticulate them. These ads, then, provided one possible framework that spectators would position their reading of the film within or against." ${ }^{33}$ Blaxploitation advertising frequently made use of tropes and slogans associated with revolutionary black nationalist groups to promote films whose narrative content actually had very little to do with such causes. Kraszewski also points out, for example, that while the adverts for Shaft suggested that the film's eponymous hero might be an ultraviolent black nationalist, the film itself shows him to be a middleclass police officer. ${ }^{34}$ It is not made clear whether the audience members whom Gene Siskel observed storming out of the Roosevelt Theater were asked exactly why they disapproved of Charley One-Eye, but the assumption that they hankered after a repeat of Shaft should not be taken as read. Shaft, too, had provided sensationalist marketing that differed from its more sedate narrative content. Perhaps they were irked that the same trick had been pulled again.

The point is that these films had multiple meanings, and adopted various strategies to profit from black audiences. We should therefore consider the possibility that some of these audiences were not being duped by the vested interests of white capital and their misleading ad campaigns, but were instead critically aware of their own ambivalent relationship to the films, and were free to accept the connotations on offer from the adverts or the films, or not. Certainly, blaxploitation westerns contain numerous indications of self-reflexivity, suggesting (and perhaps catering to) an awareness of the cultural and cinematic heritage into which the films were entering. I have already speculated that the Native's suspicion that Charley's skin color would rub off in The Legend of Nigger Charley might serve as a comment on the history of ethnic makeup in westerns. This is certainly one available reading, to an audience familiar with the traditions of black representation in Hollywood. In a similar vein of cultural-historical self-awareness, at one point in Boss Nigger Fred Williamson's hero responds to a racial slur in a saloon ("hey nigger, come here and shine my boots") by performing the exaggerated stereotype of a smiling, subservient black man: the "coon" or "pickaninny" archetype from early cinema described by Donald Bogle as an "amusement object and black buffoon ... a harmless, little screwball creation whose eyes popped, whose hair stood on end with the least excitement, and whose antics were pleasant and diverting." ${ }^{35}$ After abruptly coming out of this character and dealing deadly justice to these overt racists, the hero is accosted by the town's well-meaning Bostonian schoolmarm, who betrays the systemic prejudice of liberal white America by further affirming the "coon" archetype: "My family had black people working for us. They were good people. They used to sing and dance a lot. I used to love to watch them." Thomasine and Bushrod, too, passes comment on the pervasiveness of this character type, when a photographer expresses incredulity at the outlaw couple's ethnicity by saying: "Negroes sing and dance and steal chickens. They don't rob banks."

Of course, the most overt (indeed, unmissable) comment many of these films make on the history of racial slurs in the United States comes in their titles. Their inclusion 
of "the $\mathrm{N}$ word" is purposefully sensational, designed to foment identification among 1970s audiences eager to reclaim the word for an assertive black identity. Indeed, Fred Williamson states this purpose openly in the opening credits of the 2008 VCI DVD release of Boss Nigger: "I used the 'N' word to create sensationalism at the box office."36 As Lawrence points out, such incorporation of racial epithets into film titles also has a long cinematic heritage as films like Pickaninnies Doing a Dance (1894), A Nigger in the Woodpile (1904), and The Wooing and the Wedding of a Coon (1905) attest. ${ }^{37}$ Again, the blaxploitation western offers such a reading to a viewer attuned to this cinematic (and broader cultural) history. ${ }^{38}$

In conclusion, blaxploitation westerns' uneasy balancing act between revisionist and classical versions of the western genre can be seen to arise directly from their distribution contexts, constructing a scenario in which black outlaws are spatially and temporally disconnected from their rural surroundings so as to appeal to inner-city black audiences. Though they were in many cases distributed by major studios and made by white filmmakers, these films nevertheless adopted a variety of strategiessome obvious, some less so-for targeting these audiences. My focus has been on how these modes of address played out in these films.

To some extent, the films do of course document a moment of political revisionism in the western genre, when its ideological foundations were being brought into doubt. Yet their engagement with this generic heritage is more complex than such a surface reading might suggest, because they simultaneously demonstrate an inheritance from the genre's more "classical" elements (in particular in their framing of Native Americans), even while they seek to reject those elements' ideologies. If revisionism uncovers specific repressed histories, the blaxploitation western does not fit the bill, because these films were for the most part not addressing the history of black people on the frontier, as more prestigious black-oriented westerns of the time like Buck and the Preacher (Sidney Poitier, 1972) were..$^{39}$ Instead, these films' negotiation with the genre's history and landscape creates a tension through which their heroes perform a sort of time travel. Their urban sensibilities and articulations of black nationalism are transposed into the ideological and topographical terrain of the Wild West, almost as if they had been dropped there in a modified DeLorean, discombobulated and bewildered, from 1970s Harlem.

This, of course, should come as no surprise, given the target audiences for these films, and it perhaps explains why they do not quite "fit" into genre histories. They are neither urban blaxploitation films nor overtly historical narratives addressing specific events that contributed to the mythic Wild West. Their heroes can instead be seen as agents of transcultural appropriation across space and time. Robert A. Rosenstone sees in Alex Cox's use of creative anachronisms throughout the 1987 biopic Walker (such as helicopters, Marlboro packets, computer terminals, and Zippo lighters, all appearing an 1850s setting) an "interpenetration of past and present" that purposefully destroys any surface realism of historical representation, thereby foregrounding the continuities that lie behind the construction of historical narratives: "Beyond destroying the surface realism of the film, they work to demystify the pretensions of professional history, cast into doubt notions of historical distance and objectivity, and insist that the questions 
we take to the past always arise from our current concerns." ${ }^{30}$ For Rosenstone, Walker thus comments simultaneously on both the ideological construction of history and the traditions of representation that surround its subject: the American mercenary William Walker. Though Walker deploys anachronisms in a more overt manner than do The Legend of Nigger Charley or Boss Nigger, in their appeal to 1970s audiences blaxploitation western protagonists offer equivalently jarring readings around how dominant histories are constructed, how modes of ethnic representation operate, and how they persist into the present.

\section{Notes}

1. Tom Engelhardt, The End of Victory Culture: Cold War America and the Disillusioning of a Generation (New York: BasicBooks, 1995), 41.

2. Howard Thompson, "The Legend of Nigger Charley," The New York Times (May 18, 1972), 55.

3. Richard Slotkin, Gunfighter Nation: The Myth of the Frontier in Twentieth-Century America (New York: Atheneum, 1992).

4. Engelhardt, The End of Victory Culture.

5. Stanley Corkin, Cowboys as Cold Warriors: The Western and US History (Philadelphia: Temple University Press, 2004).

6. Engelhardt, The End of Victory Culture, 28.

7. Ibid., 22, 30, 34 .

8. See Donald Bogle, Toms, Coons, Mulattoes, Mammies and Bucks: An Interpretive History of Blacks in American Films (New York: Continuum, 2001), 101-116.

9. Julia Leyda, "Black-Audience Westerns and the Politics of Cultural Identification in the 1930s," Cinema Journal 42:1 (2002): 62-64.

10. Peter Stanfield, Hollywood, Westerns and the 1930s: The Lost Trail (Exeter: University of Exeter Press, 2001), 90.

11. Leyda, "Black-Audience Westerns," 64.

12. Cited in Ed Guerrero, Framing Blackness: The African American Image in Film (Philadelphia: Temple University Press, 1993), 83.

13. James P. Murray, "Now, a Boom in Black Directors," The New York Times (June 4, 1972), D11. Emphasis in original.

14. George McKinnon, "Movies: Especially for the Blacks," The Boston Globe (June 2, 1972), 18. Also notable here is David Church's argument that, so synonymous was inner-city movie-going with black audiences by this period, the cultural disdain aimed at grind houses carried a decidedly racially charged component: "It is difficult not to detect an echo of racial anxiety in fears the 'wrong' films and 'wrong' audiences would spread to higher-class and less inner-city parts of the New York area beyond $42^{\text {nd }}$ Street" (David Church, Grindhouse Nostalgia: Memory, Home Video and Exploitation Film Fandom (Edinburgh: Edinburgh University Press, 2015), 86 ).

15. Without wishing to labor the point, since these films' targeting of black audiences is perhaps self-evident, a snapshot of their release patterns shows how focused their distribution strategy was, even after the blaxploitation trend was past its peak. A one-page display ad of releases across the Chicago area from the Chicago Tribune of May 6, 1975 (B6), shows Boss Nigger's extensive second run playing exclusively 
in South Side cinemas: the Maryland on East 63rd Street, the Rhodes on East 79th Street, the Beverly on West 95th Street, the Jeffery on East 71st Street, the Double drive-in on West Columbus Avenue, and the Halsted on South Halsted Street.

16. This is not to say that these films have been entirely overlooked in scholarship. The release of Quentin Tarantino's own "blaxploitation western" Django Unchained (2012) has led to a degree of attention being paid to them, albeit as conduits through which to explore Tarantino's networks of citation. See, e.g., Johannes Ferle, "And I Would Call It "A Southern"': Renewing/Obscuring the Blaxploitation Western," Safundi: The Journal of South African and American Studies 16:3 (2015): 294-297.

17. Novotny Lawrence, Blaxploitation Films of the 1970s: Blackness and Genre (New York: Routledge, 2008).

18. Mikel J. Koven, Blaxploitation Films (Harpenden: Kamera, 2010), 141.

19. Bogle, Toms, Coons, 175.

20. Ibid., 175-183; Guerrero, Framing Blackness, 70-75.

21. Lawrence, Blaxploitation Films, 19.

22. Ibid., 18.

23. Leyda, "Black-Audience Westerns," 63.

24. André Bazin, "The Western, or the American Film Par Excellence," in What Is Cinema? Volume 2 (London: University of California Press, 2005), 140-148.

25. Jim Kitses, Horizons West: Anthony Mann, Budd Boetticher, Sam Peckinpah: Studies of Authorship Within the Western (London: Thames and Hudson, 1969), 11.

26. Reneé Ward. "Black Films, White Profits," The Black Scholar 7:8 (1976): 13-14.

27. Boss Nigger's association with the independent company Dimension Pictures perhaps sets it apart as a film that was not distributed for the profit of one of the major studios. Dimension was, however, very much geared toward the programmatic exploitation of profitable markets. For more on Dimension's marketing strategies, see Fred Olen Ray, The New Poverty Row: Independent Filmmakers as Distributors (London: McFarland, 1991), 149-174.

28. George Gent, "Black Films Are In, So Are Profits," The New York Times (July 18, 1972), 22; Clayton Riley, "Shaft Can Do Everything-I Can Do Nothing," The New York Times (August 13, 1972), D9; Lonne Elder III, “This May Seem Bitter," The New York Times (December 17, 1972), D19.

29. Riley, "Shaft Can Do Everything," D9.

30. Gene Siskel, "Charley One-Eye," Chicago Tribune (May 9, 1973), C8.

31. John Kraszewski, "Recontextualizing the Historical Reception of Blaxploitation: Articulations of Class, Black Nationalism, and Anxiety in the Genre's Advertisements," The Velvet Light Trap 50 (2002): 48.

32. Barbara Klinger, "Digressions at the Cinema: Reception and Mass Culture," Cinema Journal 28:4 (1989): 11-13.

33. Kraszewski, "Recontextualizing the Historical Reception of Blaxploitation," 49.

34. Ibid., 59.

35. Bogle, Toms, Coons, 7.

36. It is therefore notable that the packaging of the same DVD titles the film simply as Boss, perhaps pointing to an increased squeamishness around this word in the twenty-first century. As Ferle demonstrates, this very issue has come to the fore in the discourse surrounding Django Unchained (2012) (Fehrle, "And I Would Call It 'A Southern,"' 291-293). 
37. Lawrence, Blaxploitation Films, 1.

38. It is worth mentioning Blazing Saddles (Mel Brooks, 1974) in this context, since this also addresses American cinema's uneasy relationship with racial slurs, albeit in an altogether more comedic manner. Its depiction of a black sheriff arriving in a racist frontier town perhaps places it as an inspiration for Boss Nigger, which was released the following year, but it was not aimed so purposefully at black audiences as were the blaxploitation westerns considered here, and is therefore outside the remit of this chapter.

39. The notable exception to this rule is Soul Soldier, which addresses the history of the Buffalo Soldiers.

40. Robert A. Rosenstone, Visions of the Past: The Challenge of Film to Our Idea of History (Cambridge MA: Harvard University Press, 1995), 148-149. 
